\title{
Curcumin Prevents Chromium Induced Sperm Characteristics In Mice
}

\author{
K Rudrama Devi*, M Mosheraju and K Dilip Reddy \\ Human Genetics and Molecular Biology Laboratory, Department Of Zoology, Osmania University, Hyderabad 500007 \\ *Professor, Department of Zoology, University College of sciences, Osmania University, Hyderabad -500007, Andhra \\ Pradesh, India.
}

\begin{abstract}
Chromium was discovered in 1797 and found in all phases including air, water, and soil biota. Major uses of hexavalent chromium are metallurgical metal plating leather tanning etc. In spite its uses it has been reporting ITAR 1990 as a potent carcinogen teratogen and mutagen. The clastogenic potential of chromium has been well documented. In contrast to the activity of chromium, curcumin is a yellow colored derived from powdered rhizome Curcuma Longa is useful for the treatment of many disorders inflammation, skin wounds, certain tumors. Hence in the present investigation, studies were carried out to evaluate the protective role of curcumin on chromium induced gentoxicity in germ cells of male mice. In the present study four batches were of animals were maintained. Group II animals were given $60 \mathrm{mg} / \mathrm{kg}$ of chromium once in a week, whereas group III mice were given curcumin 5 and $7.5 \mathrm{mg} / \mathrm{kg}$ for five weeks. Group IV animals were pretreated with 5 and $7.5 \mathrm{mg} / \mathrm{kg}$ curcumin for 5 weeks plus chromium $60 \mathrm{mg} / \mathrm{kg}$ once in a week. All the animals were sacrificed on the $35^{\text {th }}$ day and cauda epidymis was processed and slides were screened for the incidence of various types of sperm head abnormalities. A significant increase was observed in chromium treated animals. However when animals pretreated with curcumin, the percentage of sperm characters decreased the significance of two dose levels. Thus the results clearly indicate the protective effect of curcumin against chromium damage in mice.
\end{abstract}

Key words: Curcumin, chromium VI, Metaphases, sperm head abnormalities.

\section{Introduction}

Elemental chromium was first discovered and characterized by a French chemist Nicolas - Louis vanquelin in Siberian red lead ore Crocoite in 1797, (Costa and Klein 2008). It is naturally elements in crustal abundance and is found virtually in all pahses including air, water, soil and biota (Losi et al., 1994).The major industries using chromium are the metallurgical, chemical and refracotyr brick industries (Losi at al., 1994). Major uses of hexavalent chromium compounds include metal plating, manufacture pigments and dyes, corrosion inhibitors chemical synthesis, refractory production leather tanning and wood preservation (Blade at al., 2007, Shanker at al., 2005)

Chromium has been studied for its potential genotoxicity in rats and mice (Wang et al., 2006, Devi 2001, Kiran et al., 2000) in chromium exposed population (Wu et al., 2000, Sarto et al., 1982, Gambelunghee at al 2003). It induced DNA damage by suppressing both DNA replication and transcription (Xu et al., 2004). It induces tumor in experimental animals and chromosomal aberrations, sister chromatid exchanges, cell transformations, gene mutations in mammalian cell cultures (Manning et al., 1994). Chromium and its intermediates interact directly with DNA to form DNA complexes that results in DNA protein and DNA amino acids crosslink (Tsouet et al., 1996). Workers occupationally exposed to chromium are considered to be an elevated risk for developing cancer through inhalation (Gibbs et al., 2000, De flora 2000).

Curcumin (Dieteruloylmethane) in a yellow pigment derived from rhizome of the plant Curcuma Longa. The powdered rhizome of this plant called turmeric is commonly used in curries preparation. It has preservative, flavoring and coloring properties of the diet, turmeric has been used in Asian medicine for generations for the treatment of many disorders, inflammation skin wounds, hepatic and biliary disorders cough, as well as certain tumors (Agarwal et al., 2003, Sharma et al., 2005). It has been shown to have a wide spectrum of biological actions, these include anticarcinogenic, anti mutagenic and anti bacterial properties (Goel et al., 2000, Egan et al., 2004, Singh et al., 2007, Sandhya Rani and Rudrama Devi 2001, 2002). Curcumin showed modulatory effects of on the levels of benzo (a) pyrene induced DNA addicts in the rat liver (Mukundan 1993). Pretreatment with curcumin gave protection against radiation induced cellular damage (Thresiamma 1998). However, no concrete evidence is available to indicate the protective effect of curcumin on heavy metal chromium IV induced genotoxicity based on evaluation of sperm morphology protocol. Hence in the present investigation an effort has been made to test the efficacy of curcumin against chromium induced genotoxic damage in germ cells of mice. 


\section{Materials and Methods: \\ Chemicals:}

Chromium VI, potassium dichromate (Molecular.Wt 291.26) molecular formula $\mathrm{K}_{2} \mathrm{Cr}_{2} \mathrm{O}_{7}$, Curcumin crystalline $\mathrm{C}_{21} \mathrm{H}_{20} \mathrm{O}_{6}$ was procured from Labo chem. Pvt. Ltd. The following features were noted. Molecular weight $=368.39$, Minimum assay (Acidimetric $99 \%$ Melting point $=170-180^{\circ} \mathrm{C}$.

\section{Animal Treatment:}

The study was conducted after obtaining permission by Institution ethical committee On twenty four adult male Swiss albino mice 22-40 days old and weighing around 25 to $35 \mathrm{~g}$ were maintained in plastic cages under sterile conditions with relative humidity $50-51 \%$ and temperature $37 \pm 2^{\circ} \mathrm{C}$ fed with feed and were given adlibitum access to a group 6 mice per experiment were procured and treated with potassium dichromate and curcumin. The doses were freshly prepared before treatment schedule only. The dose protocol was as follows Group 1 - control group (a) were treated only vehicle (water) for a day. Group II control group were treated with curcumin 5.0 \& 7.5mg/animal/day for five weeks. Group III experimental group were administered with potassium dichromate $60 \mathrm{mg} / \mathrm{kg} / \mathrm{animal}$ for once in a week. Group IV experimental batch were pre treated with curcumin $5.0 \& 7.5 \mathrm{mg} / \mathrm{animal} /$ day for 35 days and a weekly treatment of chromium IV $60 \mathrm{mg} / \mathrm{kg} /$ day $/$ animal was administered.

\section{Sperm morphology assay:}

On the 7th day, $1 \mathrm{hr}$ after priming with curcumin, highest concentration of chromium was given orally to the animals on every 7 th day for 5 weeks. Animals were killed on the 35th day after administration of the test chemical. The controls and treated group of animals were sacrificed by cervical dislocation. The animals were scarified on the 35th day after last treatment and sperm smears were prepared following the method recommended (Wyrobek and Bruce 1978). A total 2000 sperms per animals were scored for the incidence of different types of sperm head abnormalities such as banana, hammer head, head less, amorphous. The data was statistically analyzed using chi-square test. The protocol was approved by Institutional ethical committee of Osmania University, Hyderabad Andhra Pradesh.

\section{RESULTS}

\section{Sperm head abnormality:}

Sperm head abnormalities were classified into amorphous head, banana shaped head, without hook and hammerhead. The number of sperm head abnormalities were increased to 172-438 with in five weeks in the group of mice received $60 \mathrm{mg} / \mathrm{kg}$ of chromium (fig.3). A significant decrease in the percentage of abnormal sperm was observed in the group pretreated with the curcumin ( 5 and $7.5 \mathrm{mg} / \mathrm{kg}$ ) from $3.5 \%$ to $3.6 \%$ in comparison with chromium treated group. $\mathrm{P}<0.001$ (Table 1). The difference in the percentage of sperm head abnormalities between the control and group were analyzed using student t-test.

\section{Discussion:}

Cytogenetic methods for clastogenic activity environmental pollutants are routine testing programmes. The in vivo cytogenetic analysis of chromosomal aberrations is one of best methods to evaluate the clastogenic activity of chemicals drugs and environmental pollutions. Using analysis of sperm morphology assay in germ cells of mice is being carried out from our lab from the last two decades with heavy metals, like lead, cadmium and chromium, drugs such as cisplastin etc. (Kiran et al., 1999, Anuradha and Rudrama Devi 2009).

Curcuma Longa is a mandatory food additive and an individual in his diet 1-5g/day of powdered form of curcuma (Turmeric), which acts as a cleaning agent renders to protect against any diseases (Aggarwal et al., 2003,). Several in vitro and in vivo studies showed the therapeutic potential of curcumin and protective effects of curcumin. It is anti inflammatory, anti hepatoxic, scabies, cancer, Alzimeir's disease. (Hatcher et al., 2008, Ergan et al., 2004). An effort has been made in the present investigation to assess whether such toxic effects induced by chromium IV are neutralized or counter balanced by administration of curcumin. In addition to its preservative, flavoring or coloring properties in the diet, turmeric has been used in Asian medicine for generations for the treatment of many disorders including inflammation hepatic, biliary disorder cough and certain tumors based on short term studies conducted in animals and it humans that curcumin is a safe agent when administered orally (Agarwal 2003, Johnson 2007, Sharma 2005). No treatment toxicity was reported in 25 patients taking curcumin at concentrations upto $8000 \mathrm{mg} / \mathrm{day}$ for a period of 3months. Curcumin has also been shown as an immunostimulant and immunorestor in in vivo this mechanism may also participate in cancer preventive activity (Jagetia et al., 2008) and antimutagenic (Sandhya Rani and Rudram Devi 2001, Iqbal et al., 2003). 


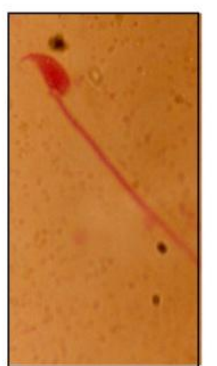

a) Normal sperm head

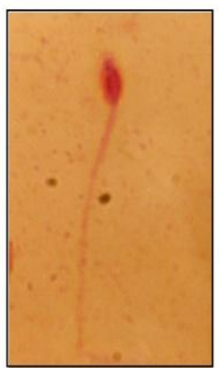

b) Banana like sperm head (Abnormal)

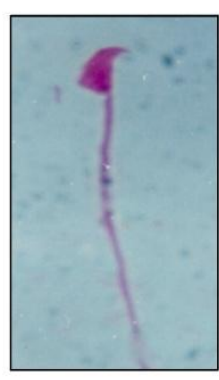

c)Amorphous shaped sperm head (Abnormal)

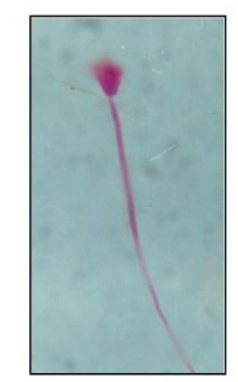

d) Hammer shaped sperm head (Abnormal)

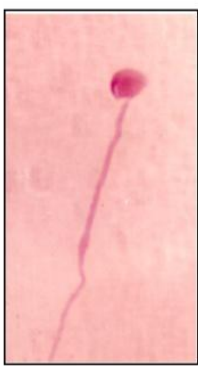

e) sperm with pin head shaped head (Abnormal)

Fig: Incidence of Sperm Head Abnormalities induced by Chromium in male mice

Table: Protective effects of curcumin on chromium induced sperm alterations in mice

\begin{tabular}{|c|c|c|c|c|c|c|c|}
\hline Group /dose & Normal sperms & \multicolumn{4}{|c|}{ Sperm head abnormalities } & \multicolumn{2}{|c|}{ Abnormal sperms } \\
\hline & & A & B & $\mathrm{H}$ & HL & No. & $\%$ \\
\hline I control & 4828 & 53 & 41 & 32 & 46 & 172 & 344 \\
\hline $\begin{array}{l}\text { II chromium } \\
60 \mathrm{mg} / \mathrm{kg}\end{array}$ & 4542 & 192 & 108 & 162 & 92 & 458 & $9.16 \mathrm{a}^{*}$ \\
\hline $\begin{array}{l}\text { III curcumin } \\
50 \mathrm{mg} / \mathrm{kg}\end{array}$ & 4830 & 60 & 36 & 40 & 34 & 170 & 3.50 \\
\hline $7.5 \mathrm{mg} / \mathrm{kg}$ & 4820 & 64 & 42 & 44 & 32 & 180 & 3.60 \\
\hline $\begin{array}{l}\text { IV curcumin }+ \\
\text { chromium } \\
5.0+60 \mathrm{mg} / \mathrm{kg}\end{array}$ & 4560 & 82 & 86 & 90 & 52 & 318 & $6.97 * b$ \\
\hline $7.5+60 \mathrm{mg} / \mathrm{kg}$ & 4630 & 90 & 70 & 64 & 46 & 270 & $5.83 * b$ \\
\hline
\end{tabular}

$\mathrm{P}<0.01$

a- Denotes significance when compared with control group

b- $\quad$ Denotes significance when compared with chromium treated group

However the geno-protective nature of curcumin has not been evaluated against chromium induced genotoxic damage and protection by curcumin. Hence it can conclude that antioxidant such as curcumin protects the body from damage to free radicals. Further curcumin, a hydrophobic polyphenol has a wide spectrum of biological and pharmacological activities. It is a bis- $\alpha, \beta$ - saturated, $\beta$ - diketone ( diferuloy/methane) which exhibits keto-enol tautomerism having a predominant keto form to acidic and neutral solutions and stable enol form in alkaline medium (Anand 2007), Due to polyphenolic structure $\beta-$ diketone functional group. Curcumin is able to scavenge or neutralize free radicals by interacting with oxidative cascade, quenches oxygen and by chelating some metal ions and inhibits per oxidation of membrane lipids there by maintaining membrane integrity and their function ( Pulla 1994). Curcumin has been shown strong antioxidant activity and studies have shown curcumin reduce oxidative stress (Iqbal et al., 2003, Cheng 2001). Curcumin protects islets against streptozotocin induced oxidative stress by scavenging free radicals (Meghana 2007). These observations are in according with our results where curcumin has been shown to render protection against chromium induced germ cell toxicity (Table.2). According to the reported studies curcumin raises the antioxidants status as wells as cause's stimulation of $\mathrm{O}^{6}$ - Methyl guanine DNA methyl transferase MGMT, a protein required for cellular protection (Niture et al., 2007, Rajeshwari 2006). Besides this curcumin induces $\mathrm{HO}^{-1}$ (That increases heme oxygenase activity) donates $\mathrm{H}$ atoms from phenolic group and inhibits iNOS induction leading to anti oxidant effect (Motterlini et al., 2000, Onoda and Inano 2000). It can be concluded that if organisms are administered with curcumin for longer period of time than perhaps toxic agents such as chromium VI might not be effective in induction of sperm head abnormalities in germ cells of mice. 


\section{Acknowledgements:}

The authors are thankful to Prof P Umamaheshwar Reddy, Head department of zoology, Osmania University, Hyderabad.

\section{References:}

- Aggarwal B. B., Kumar A, Bharti A.C. Anticancer potential of curcumin preclinical and clinical studies. Anticancer Res. 23, 363-398, 2003.

- $\quad$ Anand P, Knnumakkara AB, Newman RA, Aggarwal BB. Bioavailability of curcumin: Problems and Promises. Mol. Pharmaceutics 4(6):807-818, 2007.

- $\quad$ Blade LM, Yencken MS, Wallace ME, Catalano JD, Khan A, Topmiller JL, Shulman SA, Martinez A, Crouch KG, Bennett JS.. Hexavalent chromium exposures and exposure-control technologies in American enterprise: results of a NIOSH field research study. J Occup Environ Hyg 4:595-618, 2007.

- $\quad$ Cheng AL, Hsu CH, Lin JK, Hsu MM, Ho YF, Shen TS, Ko JY, Lin JT, Lin BR, Ming-Shiang W, Yu HS, Jee SH, Chen GS, Chen TM, Chen CA, Lai MK, Pu YS, Pan MH, Wang YJ, Tsai CC, Hsieh CY. Phase I clinical trial of curcumin, a chemopreventive agent, in patients with high-risk or pre-malignant lesions, Anticancer Res., 21, 2895-2900, 2001.

- $\quad$ Costa, M.; Klein, C.B. Toxicity and carcinogenicity of chromium compounds in humans. Crit Rev Toxicol 36(2): $155-163,2008$.

- De Flora, S. Threshold mechanisms and site specificity in chromium (VI) carcinogenesis. Carcinogenesis, 21, 533-541, 2000.

- $\quad$ Dana Devi K, R Rozati, B Saleha Banu, K Jamil, P Grover'. In vivo genotoxic effect of potassium dichromate in mice leukocytes using comet assay. Food Chem Toxicol 39(8):859-865, 2001.

- $\quad$ Egan ME, Pearson M, Weiner SA, Rajendran V, Rubin D, Glockner-Pagel J, Canny S, Du K, Lukacs GL, Caplan MJ. 2. Curcumin, a major constituent of turmeric, corrects cystic fibrosis defects. Science 23; 304(5670):600-2, 2004.

- $\quad$ Gambelunghe A, Piccinini R, Ambrogi M, Villarini M, Moretti M, Marchetti C, Abbritti G, Muzi G. Primary DNA damage in chrome-plating workers. Toxicology 188(2-3):187-195, 2003.

- Gibbs H. J., Lee P. S., Pinsky PF and Rooney B.C Lung cancer among workers in chromium chemical production Amj. Ind. Med. 38 606, 2000.

- Hatcher H, Planalp R, Cho J, Torti FM, Torti SV. Curcumin: from ancient medicine to current clinical trials. Cell. Mol. Life Sci. 65 (11): 1631-52, 2008.

- Igbal M, Sharma SD, Okazaki Y, Fujisawa M, Okada S. Dietary supplementation of curcumin enhances antioxidant and phase II metabolizing enzymes in ddY male mice: possible role in protection against chemical carcinogenesis and toxicity. Pharmacology and Toxicology, 92: 33-38, 2003.

- Jagetia, G. C., Aggarwal, B. B., "Spicing up" of the immune system by curcumin, J. Clin. Immunol., 27, 19-35, 2007.

- Johnson, J. J., Mukhtar, H., Curcumin for chemoprevention of colon cancer, Cancer Lett., 265, 170-181, 2007.

- $\quad$ Kiran B., Irene D., Rudrama Devi K. Mutagenicity of Chromium in bone marrow cells of mice, Trends in Life Science., 14(2), 93-96., 1999.

- $\quad$ Losi, ME; Amrhein, C; Frankenberger, Jr, WT. Environmental biochemistry of chromium. Rev Environ Contam Toxicol 136:91-121, 1994.

- $\quad$ Manning, F.C.R., Blankenship, L.J.,Wise, J.P., Xu,J., Bridgewater, L.C. and Patieron, S.R.: Environ. Health Perspect., 3: 159-167 (1994)

- Meghana K, Sanjeev G, Ramesh B. Curcumin prevents streptozotocin-induced islet damage by scavenging free radicals: a prophylactic and protective role. Eur. J. Pharmacol. 577(1-3): 183-191, 2007.

- Motterlini R Fororesli R, Barst, Green C.J., Curcumin an antioxidant and anti inflammatory agent induces heme oxygenase 1 and portects endothelial cells against oxidative stress. Free Radial Biol. Med. 28, 1303-1312, 2000.

- $\quad$ Mukundan M.A., Chacko M.C., Annapurna V.V, Krishnaswamy. K., Effect of turmeric and curcumin on BPDNA adducts, Carcinogensis 1993, 14, 493-496.

- $\quad$ Niture, S. K., Velu C. S., Smith, Q. Bhat G. J. \& Srivenugopal K.S. (2007) Increased expression of the MGMT repair protein by cysteine prodrugs and chemopreventative natural products in human lymphocytes and tumor cell lines. Carcinogenesis28 (2):378-389. 
- $\quad$ Onoda M Inano it. Effects of curcumin on production of nitric oxide by cultured rat amammary gland: Nitric oxide- 4, 505-515, 2000.

- $\quad$ Pulla RA, Lokesh BR. Effect of dietary turmeric (Curcuma Longa) on iron-induced lipid peroxidation in the rat liver. Food Chem. Toxicol. 32: 279-283, 1994.

- $\quad$ Rajeshwari A. Curcumin protects mouse brain form oxidative stress caused by 1-methyl 4-phemyl 1, 2, 3, 6 tetrahydroxy pyridine. Eur. Rev. Med. Pharmaecology sci. 10, 157-161, 2006.

- $\quad$ Arun K. Shanker,T Carlos Cervantes, Herminia Loza-Tavera, S. Avudainayagam. Chromium toxicity in plants. Environ Int 31:739-753, 2005.

- $\quad$ Sharma RA, Gescher A. J. Steward W.P. Curcumin. The story sofar Eur. J. Cancer 41, 1955-1968, 2005.

- $\quad$ G. Sandhya Rani and K. Rudrama Devi "Effect of curcumin in germ cells of swiss albino male mice", Trends in life sciences 16(2):2001. 75-79

- Thresiamma KC, George J, Kuttan R. Protective effects of curcumin, ellagic acid and bixin on radiation induced genotoxicity. J.Exp. Clin. Cancer Res. 17: 431-434, 1998.

- $\quad$ Tsou T-C, Chen C-L, Liu T-Y, Yang J-L. Induction of 8-hydroxydeoxyguanosine in DNA by chromium(III) plus hydrogen peroxide and its prevention by scavengers: Carcinogenesis, 17(1):103-108(1996)

- $\quad$ Wang XF, Xing ML, Shen Y, Zhu X, Xu LH.. Oral administration of Cr(VI) induced oxidative stress, DNA damage and apoptotic cell death in mice. Toxicology 228(1):16-23, 2006.

- Wyrobek, A.J. and W.R. Bruce: Chemical induction of sperm abnormalities in mice. Proc. Nat. acad. Sci., 72, 4452-28(1975).

- Wu F.Y., Tsai F. J., Kuo H. W., Tsaich H., Cohen H., Costa M and Tonolo P DNA protein corsslinks in peripheral lymphocytes of individuals exposed to hexavalent chromium compounds. Biomarkers 1, 86-93, 1996.

- $\quad$ Xu J, Manning FC, O'Brien TJ, Ceryak S, Patierno SR Mechanisms of chromium-induced suppression of RNA synthesis in cellular and cell-free systems: relationship to RNA polymerase arrest. Mol Cell Biochem. 2004 Jan; 255(1-2):151-60. 